\title{
COVID-19: the transition towards a new normal-experiences from the European country of Malta
}

\author{
Sarah Cuschieri ${ }^{1}$ (D)
}

Received: 21 June 2020 / Accepted: 4 February 2021 / Published online: 21 February 2021

(C) The Author(s), under exclusive licence to Springer-Verlag GmbH, DE part of Springer Nature 2021

\begin{abstract}
Aim The COVID-19 pandemic has caused a global change in the way of living. In late spring, a number of Northern Hemisphere countries were in a transition period from lockdown to a new normality. Malta, a European country, praised by the Commonwealth General Secretary as the country that 'has done the best in the whole of Europe' was also at this stage. The aim was to summarise the transition period in Malta while describing the different transition phases and interventions adopted to return to a new normality.

Subject and method A literature search was conducted using Google search engines and Maltese online newspapers.

Results Up till 21 June 2020, a total of 665 cases were identified, with 40 cases being active and nine deaths. Eight weeks after the first reported COVID-19 case, the first transition phase with relaxation of some lockdown measures came into effect. A spike in positive cases was observed after this phase. The second and third transition phases followed suite in 2 week intervals, at the end of which all services were re-opened. However, the travel ban was to be lifted on 1 July 2020. Of note, the number of positive cases remained relatively low after the latter two transition phases.

Conclusion Malta's COVID-19 response team managed to contain the first wave following an all-of-society and all-ofgovernment approach. The healthcare system was equipped with an adequate number of beds and ventilators. The three transition phases instituted have shifted the Maltese population from a partial lockdown to a new normality with low fluctuating COVID-19 daily positive cases during the transition period.
\end{abstract}

Keywords Pandemic $\cdot$ Coronavirus $\cdot$ Malta $\cdot$ Global health $\cdot$ Population health

\section{Introduction}

Over a few months, the globe experienced drastic lifestyle changes as COVID-19 spread from China to the rest of the world. This viral infection was declared as a pandemic by the World Health Organization (WHO) in March 2020 (World Health Organization (WHO) 2020). Governments across the globe instituted a number of measures and legislations to contain the COVID-19 infection and protect their nations. Concurrently, healthcare systems were radically transformed and expanded in preparation for COVID-19 patients.

Malta is a small European country situated in the middle of the Mediterranean Sea with a total population of 493,559 (National Statistics Office (NSO) 2020). The population

Sarah Cuschieri

sarah.cuschieri@um.edu.mt

1 Department of Anatomy, Faculty of Medicine and Surgery, University of Malta, Msida, Malta average age is 41.8 years, with an estimated $20 \%$ of the population being over the age of 65 years (National Statistics Office (NSO) 2020). Malta is densely populated (1380 per $\mathrm{Km}^{2}$ ) compared to the neighbouring countries of Italy, with a population density of 206 per $\mathrm{Km}^{2}$, and Tunisia, with a population density of 76 per $\mathrm{Km}^{2}$.

Malta was reported to have instituted timely public health measures during the first wave that were exemplary and acknowledged by the WHO Europe Regional Director, Dr. Hans Henri P. Kluge in March 28th 2020 (Grech Urpani 2020a). On 9 May it was reported that Malta was considered as the "most trusted healthcare system in the whole European Union' (Grech Urpani 2020b). Similar praise was given a couple of weeks later, when on 30 May, the Commonwealth General Secretary reported that Malta "has done the best in the whole of Europe" (CDE News 2020). It appears that Malta managed to contain the first wave of COVID-19, following early implementation of interventions along with advocating for personal hygiene, social distancing and contact tracing. This led to minimal fatalities and containment of the spread of the virus 
(Cuschieri 2020). Malta, similar to other countries, started to transition from an almost full lockdown to returning to a "new normal' by late Spring 2020. This report aimed to give (i) a comprehensive summary of the COVID-19 situation in Malta during the transition period (up to 1 July 2020), (ii) describe the phases of transition instituted by the Maltese Superintendent of Public Health in conjunction with the Ministry for Health and Government of Malta and (iii) describe the relaxation interventions adopted to return to a new normality.

\section{Subject and method}

A literature search was conducted using Google search engines and Maltese online newspapers using the keywords 'COVID-19', 'Malta', 'Restrictions' and 'Mitigations'.

\section{Results}

\section{COVID-19 spread in Malta}

The first COVID-19 case reported in Malta was on 6 March 2020 (Cuschieri 2020). However, COVID-19 preparations had been instituted way before this first case was identified. Malta had direct contact with China early on and health officials were brought to speed on what to expect once COVID-19 hit the islands. This communication was one of the keys to the success in dealing with the first wave of COVID-19 in Malta. Another advantage was the fact that a Maltese public health physician working at the WHO office of China provided invaluable aid and information about this pandemic (Caruana 2020a).

During the first wave, the death rate in Malta was one of the lowest in Europe, with only 1.3\% of those testing as COVID19 positive in Malta having either been seriously ill or died, unlike the situation in the European Union, where an average of $11.3 \%$ fell under these catagories (Department of Information 2020a). As expected, a male predominance was identified as having COVID-19 when compared to the female counterparts (Collier 2020; Cuschieri 2020). Malta was 40th out of 48 European countries and the 143th country out of 215 global countries and territories with regard to COVID-19 positive cases (Worldometer 2020). The highest number of recorded positive COVID-19 cases on a single day during the first wave was 52 cases on 7 April, after which the number of daily active cases fluctuated (range 0 cases to 38 cases), as seen in Fig. 1 (COVID-19 Public Health Response Team Ministry for Health 2020). The highest affected population age group was between 30 and 34 years (Fig. 2). The 26th of April 2020, marked the first time after 6 weeks when no new positive cases were reported (Times of Malta 2020a).

\section{Malta's COVID-19 transition period}

Two months following the first case of COVID-19 in Malta, the Islands moved into the first transition phase towards a new normality. This followed emerging evidence that COVID-19 transmission was controlled, while the health system capacities were adequate and in place (World Health Organization 2020a). This transition was permissible and followed the formulation of large-scale restrictive public health measures, such as identification and isolation of positive cases, quarantine of all COVID-19 positive contacts along with the advocacy for personal protective measures and social distancing, as advised by the World health Organization (World Health Organization 2020a). In fact, the Mayo Clinic Chief praised Malta for its 'quick and comprehensive' response to the COVID-19 pandemic (Arena 2020).

A COVID-19 symptom application was introduced on the 30th of April and the Maltese population was invited to use this app willingly. The app was designed to gather anonymous data but at the same time enable the Superintendence of Public Health along with the COVID-19 Public Health Response Team to assess and predict the spread of the coronavirus in Malta (Caruana 2020f).

The first transition phase with relaxation of lockdown measures came into effect on the 3rd of May 2020 (Caruana 2020b). A spike in positive cases was observed just 10 days after this first transition phase, where 14 new cases were reported on the 14th of May 2020, as seen in Fig. 3. The following week, the number of identified positive cases remained slightly elevated, ranging between 5 to 15 cases (between 15 and 21 May 2020). One can postulate that this rise in COVID-19 positive cases was directly related to the relaxation of some lockdown measures. However, after 2 weeks from the first transition phase, the number of positive cases declined drastically, as seen in Fig. 3. Of note, approximately $20 \%$ of coronavirus positive Maltese patients were asymptomatic, which is a lower rate than that reported in other countries (40-45\%) (Caruana 2020c; Oran and Topol 2020).

\section{The nations' health communication}

At the onset of COVID-19 in Malta, a daily media brief was given by the Superintendent of Public Health to inform the nation about the identified cases, recovered cases and deaths. This was followed by journalists' questions and answers. As Malta moved into the 'transition period', an official governmental social media account was created along with the already existing cross-government COVID-19 website (www. covid19malta.info), to provide COVID-19 related news and statistics. Meanwhile the daily media briefs given by the Superintendent of Public Health were reduced to three times per week (Monday, Wednesday and Friday) as of the 18th of May (Costa 2020). Later, on the 3rd of June, as the number of COVID-19 positive cases stabilised and remained low, it was 
Daily reported COVID-19 cases between March to June in Malta

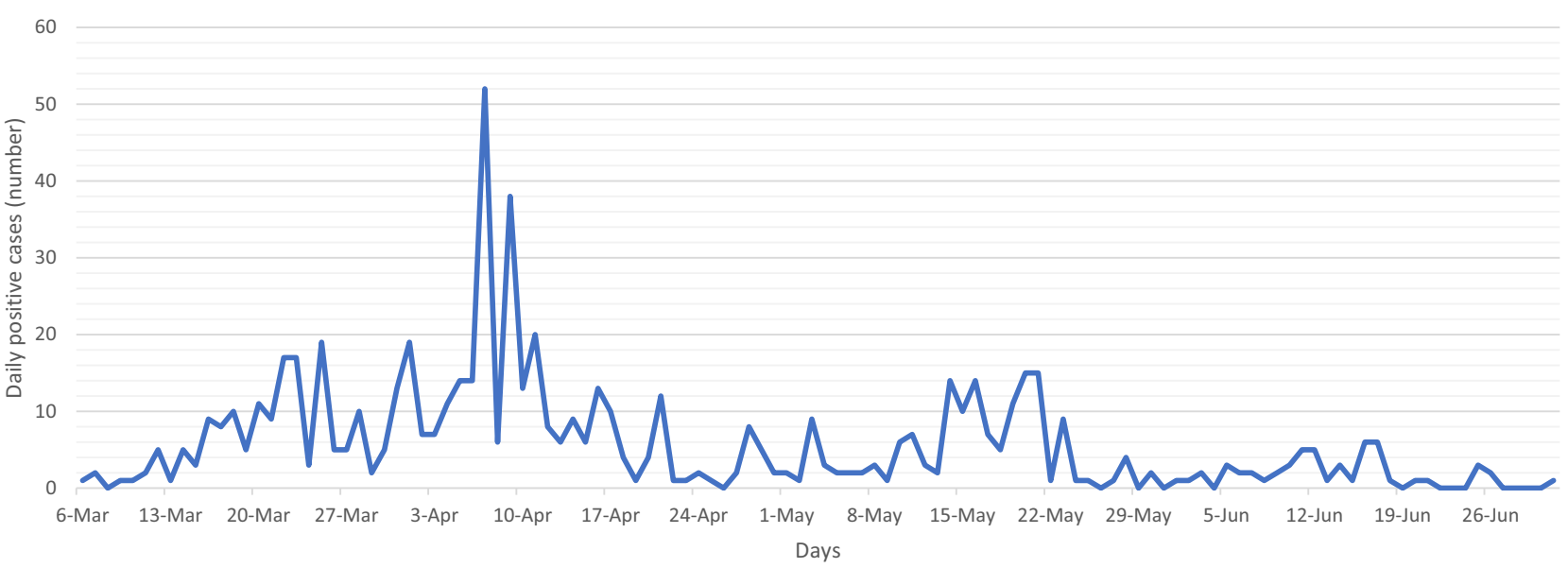

Fig. 1 COVID-19 situation during the first wave and transition period (March-June 2020) in Malta

announced that these media briefs were coming to an end (Caruana 2020d). Daily updates on the COVID-19 situation were still going to be announced through the official online sources.

\section{Monitoring and surveillance}

The transition out of the COVID-19 pandemic was based on a number of phases in line with the lowering of the 'Reproduction Factor (Rt)' as recommended by the WHO and European Centre for Disease Prevention and Control (ECDC) guidelines. Gradual relaxation of lockdown measures was considered when the Rt went below one, with the initial relaxation measures being those activities that were considered as 'low risk' (European Observatory on Health Systems and Policies 2020).

\section{Relaxation of lockdown measures}

On 22nd March 2020 during a national press-conference, all non-essential retails and services were mandated to close immediately (Cuschieri 2020). After 6 weeks, the Superintendent of Public Health in conjunction with the Ministry for Health and the Government of Malta re-opened some of the non-essential retail outlets on the 3rd of May 2020 (Caruana 2020b). The retail outlets that were allowed to re-open were principally businesses relating to selling of clothing, sportswear, jewellery, hand bags and leather goods, costume jewellery and accessories, footwear, non-prescription eye-wear, perfumeries, beauty products, haberdasheries, soft furnishings, souvenir shops, discount stores, luggage shops, toy shops, hobby shops, furniture shops and florists. This brought with it the introduction of a mandatory measure of wearing of face masks or shields, through a Public Health Act Chapter, when entering all shops (including those that were already open such as supermarkets) as well as when utilising public transport (Public Health Act Chapter 465 2020; Times of Malta 2020b). Owing to the envisaged increased demand for face masks and shields, fixed prices for disposable surgical masks of $€ 0.95$ and face shields of $€ 5.00$ were set (Times of Malta 2020c). Nonetheless, anyone not abiding to the obligation to wear face
Fig. 2 Population age range in years of COVID-19 positive cases in Malta over 3 months (COVID19 Public Health Response Team - Ministry for Health 2020)

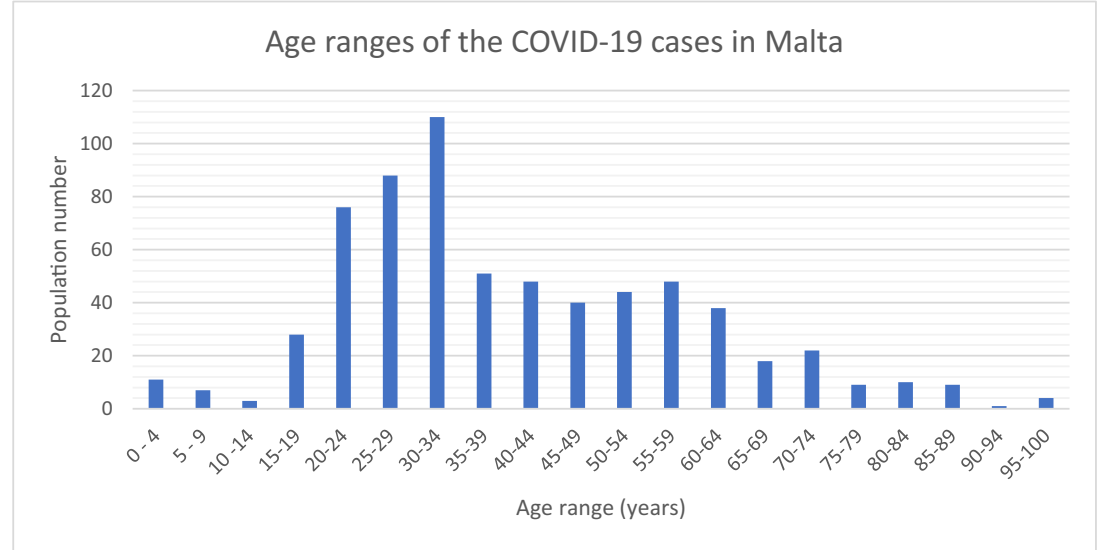




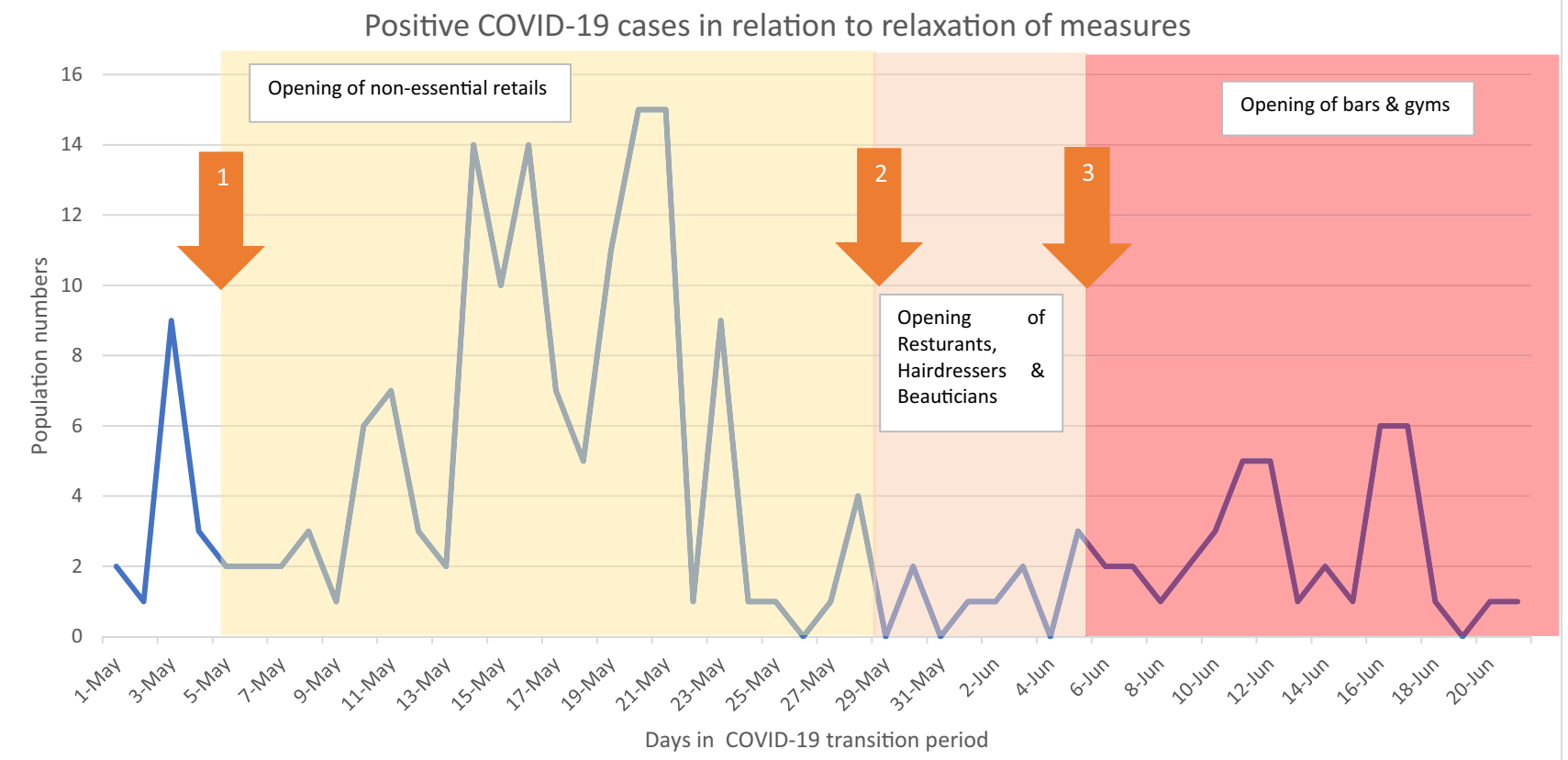

1 - Opening of non-essential retails on $4^{\text {th }}$ of May 2020

2 - Opening of restaurant, hairdressers, beauticians on $22^{\text {nd }}$ of May 2020

3 - Opening of bars and gyms on $5^{\text {th }}$ of June 2020

Fig. 3 Relationship between relaxation of preventive COVID-19 measurements and identified COVID-19 positive cases in Malta

masks or shields was not to be charged with any penalties. However the general population closely followed these obligations when visiting supermarkets, retail shops and while on public transport (Cassar 2020; TVM 2020a). The first set of lockdown relaxation measures also amended the previous ban preventing gathering of more than three people (outside the same household) introduced on the 2nd of April. This was amended to four people gathered together (KPMG 2020a; Cuschieri 2020). Furthermore, the prohibition of non-essential travel between the two sister islands of Malta and Gozo was revoked as was the closure of 'vehicles roadworthiness testing' (VRT) stations (KPMG 2020a).

The second set of lockdown relaxation measures came into effect on the 22nd of May, after 2 weeks of the first set of lockdown relaxation measures, in accordance with the WHO recommendations (World Health Organization 2020b). These lockdown relaxation measures included the permission for reopening of restaurants, cafeterias and snack bars. If these establishments had outdoor facilities, they were encouraged to provide their services outdoors. Whilst those that did not have outdoor facilities were advised to reduce their service capacity with applicable social distancing measures. A maximum of six individuals were to be allowed to be at one table. Beautician shops, including nail beauticians and hairdressers, were allowed to re-open, as long as a number of preventive measures were implemented (TVM 2020b). These preventive measures included the wearing of masks or visors by both those offering the service and the client. Temperature was checked for all clients while a two-meter distance between clients was imposed. Perspex screens were advised to be set up, where possible (TVM 2020b). Individual and group sport training were allowed in open spaces if no more than six persons were together at the same point in time. Outdoor pools were also opened provided that half the normal capacity number were allowed to use the pool (TVM 2020b). The number of persons allowed to gather in public spaces was increased from four to six (KPMG 2020b). In order to aid the various entities to follow the obligatory conditions, a number of guidelines were provided by the 'Malta COVID-19 Public Health response team' in conjunction with the Superintendent of Public Health and issued under the Public Health Act chapter 465 (Superintendent of Public Health 2020a).

Concurrently, the health care services that had been previously suspended within the primary care setting, including the diabetic clinics, heart disease clinic and well-baby clinic, were resumed. The outpatient appointments within the only state hospital of Malta, Mater Dei Hospital, were also to be increased along with the radiological services and the nonurgent operations such as elective orthopaedics, gynaecology and ophthalmology. Screening programmes for cervix and colon were also resumed (TVM 2020c). Furthermore, religious funeral masses could be resumed albeit still with a reduced number of attendees. Where possible, such religious activities were to take place in an open environment (TVM 2020d).

The third set of lockdown relaxation measures came into effect on the 5th of June 2020. These included the re-opening 
of the rest of the non-essential retails and services, including bars, cinemas, exhibition centres, museums, night clubs, indoor swimming pools, massage parlours and gyms among others (Borg 2020a; KPMG 2020c, d). Although teleworking was still encouraged, office workers were expected to return to their workplace while childcare centres re-opened. These relaxation measures were subject to the implementation of established sector-specific health risks mitigation measures (temperature checking, hand hygiene, mask wearing, physical distance of more than four square meters apart, etc.) (Caruana 2020e; Superintendent of Public Health 2020a). Religious services recommenced on the 13th of June 2020 following a number of conditions, including physical distancing and wearing of face masks or shields (Martin 2020a; Micallef 2020). The number of individuals gathered together was no longer limited to just six persons but went up to 75 persons; however, organised mass events remained prohibited (KPMG 2020c).

The complete travel ban that had been instituted on the $21 \mathrm{st}$ of March was partially lifted for a number of countries on the 1st of July (Martin 2020a; Cuschieri 2020). Travelling was set for 24 countries/regions, including Austria, Croatia, Cyprus, Czech Republic, Denmark, Estonia, Finland, France (except for Ile de France), Germany, Greece, Hungary, Ireland, Iceland, Italy (excluding Emilia Romagna, Lombardy and Piemonte), Latvia, Lithuania, Luxembourg, Norway, Poland (except for Katowice Airport), Sardinia, Slovakia, Sicily, Spain (except for Madrid, Catalonia, Castilla- La Mancha, Castile and Leon) and Switzerland (Borg 2020b; Times of Malta 2020d; KPMG 2020c). Travellers arriving from these 'safe' countries were not obliged to undergo a COVID-19 swab test nor to enter a quarantine when they landed in Malta (Times of Malta 2020e). On the 15 th of July the travel ban was fully lifted with the aim that normality would return (Borg 2020b).

The gradual relaxation of the restrictive measures enabled surveillance of the situation. In fact, on 15 June, it was announced that in Malta, COVID-19 was no longer considered as a public health emergency (Borg 2020b; Times of Malta 2020f). This meant that legal notices for the closure of schools and law courts along with control on social gatherings were reverted (Times of Malta 2020f). However, should the restrictive measures have been lifted abruptly, an increased risk of morbidity and mortality rate could have presented.

\section{Vigilance and caution}

The Superintendent of Public Health with the Ministry of Health and Government of Malta continuously advocated that although the lockdown restrictions were waved, the population still needed to remain vigilant and abide by the various new normality preventive measures (TVM 2020e). A number of different guides were formulated by public health experts under the remit of the Superintendent of Public Health to aid in this transition as can be found on: www.covid19health.gov. $\mathrm{mt}$, including guidance for the protection of vulnerable persons. Although the spread of COVID-19 appears to have been contained, a number of healthcare professionals voiced their concerns and advised that the lifting of the containment measures might need to be reverted if there is a new spike in COVID-19 positive cases (Calleja 2020; Xuereb 2020). Furthermore, a chorus of recommendations were positioned to continue with social distancing as well as the widespread availability and encouragement for COVID-19 swabbing in any doubtful situations. All this whilst continuing to surveil the nation's COVID-19 situation, following evidence-based data and recommendations (Calleja 2020; Times of Malta 2020g; Xuereb 2020).

\section{Discussion}

\section{Reasons for a sustainable 1st COVID-19 wave in Malta}

The Maltese Islands are made up of two sister islands (Malta and Gozo) with a total archipelago area of $136 \mathrm{Km}^{2}$ situated in the middle of the Mediterranean Sea. Although the small 'islandness' state serves as a disadvantage in a number of situations, for the fight against COVID-19, this geographical factor had an advantageous role. It was easy to control the borders, by closing just one port and one airport, without any concerns about land borders. The small size of the nation provided a more timely healthcare system response as well as easy access to the health services, including the four COVID19 swabbing sites, by all the population (Caruana 2020a; Cuschieri 2020).

The early preparations of the healthcare system under the guidance of the Maltese leading physician working at China's WHO office was another advantage for Malta. Topped up with the timely closure of the airport, schools and nonessential shops, all this proved essential to prevent the importation and the extensive spreading of the virus. The vigorous testing for the virus with over 1000 daily tests performed, enabled the prompt detection of symptomatic and asymptomatic individuals, isolation and containment of their contacts. Along with the swift protection of the vulnerable populations (65+ years; pregnant women; those with chronic diseases) through a mandatory Public Health Act legislation set in place on 23 March, approximately 2 weeks after the first COVID-19 cases, enabled further the containment of COVID-19 (Caruana 2020a; Superintendent of Public Health 2020b; Cuschieri 2020). The solidarity culture of the Maltese was of great help in this legislation, as the nation joined together to protect the elderly up to the extent that carers working in elderly homes locked themselves in for weeks to protect the elderly (Caruana 2020a; Cuschieri 2020). 


\section{COVID-19 and the economy}

This pandemic brought with it an economic global crisis. The closure of a number of establishments and a low tourism influx due to the imposed travel ban led to a negative economic result in Malta. In fact, in May, the Central Bank of Malta reported that the business conditions were 'nearly as bad as the great recession of 2009' (Martin 2020b). The number of unemployed individuals also double when compared to the previous year (2019) (Times of Malta 2020h). A struggle was observed between trying to maintain an adequate economy and sustaining the nation's health. Professionals advocated that a 'balance' needed to be achieved between the nations' health and economic concerns when issuing lockdown relaxation measures (Times of Malta 2020i; Grech et al. 2020). During the first wave of the pandemic, the government of Malta instituted three financial aid packages for the various companies, entities and families that experienced an economic disparity due to COVID-19 (KPMG 2020; PwC Malta 2020a, b; Cuschieri 2020). As part of the transition period, following the third phase of the lockdown relaxation measures, an extraordinary budget was set-up with the aim to aid the recovery of the economy within Malta (Times of Malta 2020j). This budget included (i) the continuation of the employment protection scheme introduced before through the COVID-19 financial aid packages, (ii) a one-time incentive for selected businesses for electricity bills subsidy during the hot summer months among other business incentives, (iii) measures for incentive consumption by providing every resident in Malta above the age of 16 years an $€ 80$ voucher redeemable at restaurants, bars and hotels and a $€ 20$ voucher redeemable at any outlet that was closed during the lock-down COVID-19 period valid till the end of September 2020, (iv) a reduction in fuel prices, (v) tax refund cheques, (vi) increase in the in-work benefit for parents with kids, among other incentives (BDO Malta 2020; Times of Malta 2020j).

\section{Conclusion}

The Malta COVID-19 Public Health response team with the help of the nation in general, managed to contain the first COVID-19 wave with minimal fatalities. This was permissible by following an all-of-society and all-of-government approach. The healthcare system was equipped with an adequate number of beds and ventilators for potential COVID-19 patients while the healthcare workforce was trained and equipped for this pandemic. Extra beds situated at different off-site venues outside the only state hospital in Malta were also made available. This included the conversion of some University of Malta lecture rooms into isolation wards, increasing the bed capacity by 42 beds for potential coincidence of COVID-19 and influenza patients come
Autumn (Department of Information 2020b; TVM 2020f). This was possible since some of the university's facilities are found within the state's hospital premises while the bulk of the university buildings are situated just across the road from said hospital. The nation was kept informed about the COVID-19 situation within Malta on a daily basis through media briefs and only when the situation became stable did these media briefs diminish and eventually come to an end. However, daily updates on the COVID-19 situation is still being presented to the population through official governmental infogram portals and social media. The three transition phases instituted over consecutive two-week periods have shifted the Maltese from a partial lockdown to a new normality with low fluctuating COVID-19 positive cases.

Funding The report has not been financed nor delegated by the Superintendent of Public Health, the Ministry of Health or the Government of Malta.

\section{Declarations}

Conflict of interest The author declares that they have no conflict of interest.

Ethics approval This is an academic report based on data that is available online.

\section{References}

Arena J (2020) Malta's "comprehensive" response to COVID-19 impressive - Mayo Clinic chief. In: Times of Malta. https://timesofmalta. com/articles/view/maltas-comprehensive-response-to-covid-19impressive-mayo-clinic-chief.789701. Accessed 9 Jun 2020

BDO Malta (2020) The Maltese Government announces a package aimed at economic recovery - BDO. In: BDO Malta. https://www.bdo. com.mt/en-gb/news/2020/the-maltese-government-announces-apackage-aimed-at-economic-recovery-a-better-tomorrow. Accessed 12 Jun 2020

Borg J (2020a) Bars, gyms to reopen Friday, airport, ports in July - Robert Abela. In: Times of Malta. https://timesofmalta.com/articles/view/ bars-gyms-to-re-open-friday-airport-ports-in-july-robert-abela. 795559. Accessed 9 Jun 2020

Borg J (2020b) No flight restrictions from July 15, public health emergency to be lifted. In: Times of Malta. https://timesofmalta.com/ articles/view/public-health-emergency-to-be-lifted-newdestinations-including-italy.798498. Accessed 14 Jun 2020

Calleja C (2020) Easing timeline 'should not be in stone,' Maltese WHO director says. In: Times of Malta. https://timesofmalta.com/articles/ view/easing-timeline-should-not-be-in-stone-maltese-who-directorsays.793583. Accessed 11 Jun 2020

Caruana C (2020a) The seven secrets to Malta's success in the COVID19 fight. In: Times of Malts. https://timesofmalta.com/articles/view/ the-seven-secrets-to-maltas-success-in-the-covid-19-fight.795508. Accessed 9 Jun 2020

Caruana C (2020b) Some shops to reopen on Monday as COVID-19 restrictions ease. In: Time Malta. https://timesofmalta.com/articles/ view/relaxation-of-some-covid-19-measures-expected-to-beannounced.789308. Accessed 9 Jun 2020 
Caruana C (2020c) Fifth of COVID-19 patients showed no symptoms. In: Times of Malta. https://imesofmalta.com/articles/view/fifth-ofcovid-19-patients-showed-no-symptoms.789038. Accessed 9 Jun 2020

Caruana C (2020d) Health briefings that made Charmaine Gauci a household name end. In: Times of Malta. https://timesofmalta.com/ articles/view/health-briefings-that-made-charmaine-gauci-ahousehold-name-end.796245. Accessed 9 Jun 2020

Caruana C (2020e) How offices will change as people return to work. In: Times of Malta. https://timesofmalta.com/articles/view/howoffices-will-change-as-people-return-to-work.796221. Accessed 11 Jun 2020

Caruana C (2020f) Health minister invites people to try COVID-19 symptoms app. In: Times of Malta. https://timesofmalta.com/articles/ view/health-minister-invites-people-to-test-covid-19-symptomsapp.788906. Accessed 9 Jun 2020

Cassar D (2020) Now that the shops have reopened, are people obeying the rules? - TVM News. In: TVM. https://www.tvm.com.mt/en/ news/now-that-the-shops-have-reopened-people-are-obeying-therules/. Accessed 10 Jun 2020

CDE News (2020) Commonwealth General Secretary says that Malta has done the best in the whole of Europe. In: CorporateDispatch.Com. https:/corporatedispatch.com/commonwealth-general-secretarysays-that-malta-has-done-the-best-in-the-whole-of-europe/. Accessed 3 Jun 2020

Collier I (2020) Coronavirus: Why does COVID-19 pose a greater threat to men than women? | World News | Sky News. In: Sky news. https://news.sky.com/story/coronavirus-why-does-covid-19-pose-agreater-threat-to-men-than-women-11964453. Accessed 15 Apr 2020

Costa M (2020) Charmaine Gauci's COVID-19 updates will now take place three times a week. In: Maltatoday. https://www.maltatoday. com.mt/news/national/102421/charmaine_gaucis_covid 19 updates_will_now take_place_three_times_a_week\#. Xt9h5i2w0cg. Accessed 9 Jun 2020

COVID-19 Public Health Response Team - Ministry for Health (2020) COVID-19 Data Management System

Cuschieri S (2020) COVID-19 panic, solidarity and equity - the Malta exemplary experience. J Public Health (Bangkok) 1-6. https://doi. org/10.1007/s10389-020-01308-w

Department of Information (2020a) Issue 69 COVID-19 Bulletin A PHASE OF TRANSITION. https://www.gov.mt/en/Government/ DOI/PressReleases/Documents/ISSUE69_ENG.pdf. Accessed 14 Jun 2020

Department of Information (2020b) Issue 61 COVID-19 Bulletin

European Observatory on Health Systems and Policies (2020) Malta COVID-19 Health System Response Monitor. In: World Heal. Organ. Eur. Reg. https://www.covid19healthsystem.org/countries/ malta/countrypage.aspx. Accessed 11 Jun 2020

Grech Urpani D (2020a) "An Example To Follow": WHO Europe Regional Director Gives Shout-Out To Malta's COVID-19 Measures. In: Lovin Malta. https://lovinmalta.com/news/newsinternational/an-example-to-follow-who-europe-regional-directorgives-shout-out-to-maltas-covid-19-measures/. Accessed 15 Apr 2020

Grech Urpani D (2020b) Beating All Other EU Countries, Malta Tops List As "Most Trusted Healthcare System." In: Lovin Malta. https:// lovinmalta.com/news/news-international/beating-all-other-eucountries-malta-tops-list-as-most-trusted-healthcare-system/. Accessed 9 Jun 2020

Grech V, Grech P, Fabri S (2020) A risk balancing act - tourism competition using health leverage in the COVID-19 era. Int J Risk Saf Med. https://doi.org/10.3233/JRS-200042

KPMG (2020a) Lifting of some COVID-19 restrictions - KPMG Malta. https://home.kpmg/mt/en/home/insights/2020/05/lifting-of-somecovid-19-restrictions.html. Accessed 10 Jun 2020
KPMG (2020b) Re-opening on establishments and public gatherings Legal Notices published - KPMG Malta. In: KPMG. https://home. $\mathrm{kpmg} / \mathrm{mt} / \mathrm{en} / \mathrm{home} /$ insights/2020/05/re-opening-of-establishmentsand-public-gatherings-legal-notice-published.html. Accessed 10 Jun 2020

KPMG (2020c) Lifting of COVID-19 restrictions - Legal Notices published - KPMG Malta. In: KPMG. https:/home.kpmg/mt/en/home/ insights/2020/06/lifting-of-covid-19-reactions-legal-noticespublished.html. Accessed 11 Jun 2020

KPMG (2020d) Lifting of COVID-19 restrictions - KPMG Malta. In: KPMG. https://home.kpmg/mt/en/home/insights/2020/06/liftingof-covid-19-restrictions.html. Accessed 11 Jun 2020

KPMG Financial packages in response to COVID-19 - KPMG Malta. $\mathrm{https} / /$ home.kpmg/mt/en/home/insights/2020/03/maltas-financialpackage-in-response-to-covid-19.html. Accessed 15 Apr 2020

Martin I (2020a) Covid-19 restrictions to be lifted on Friday, but big events still banned. In: Times of Malta. https://timesofmalta.com/ articles/view/abela-press-conference-on-easing-of-covid-19restrictions.795835. Accessed 11 Jun 2020

Martin I (2020b) Economic conditions similar to "the great recession", says Central Bank. In: Times of Malta. https:/timesofmalta.com/ articles/view/economic-conditions-similar-to-the-great-recessionsays-central-bank.793682. Accessed 11 Jun 2020

Micallef K (2020) Masks mandatory as Masses to resume on June 13. In: Times of Malta. https://timesofmalta.com/articles/view/watcharchbishops-statement-on-resumption-of-masses.795924. Accessed 11 Jun 2020

National Statistics Office (NSO) (2020) Regional statistics Malta 2020 edition

Oran DP, Topol EJ (2020) Prevalence of Asymptomatic SARS-CoV-2 Infection. Ann Intern Med M20-3012. https://doi.org/10.7326/ M20-3012

Public Health Act Chapter 465 (2020) Passenger / Service Provider conditions when using Public Transport Services Applicability Scheduled Public Transport Services Persons using the service

PwC Malta (2020a) Financial aid package and measures introduced in light of COVID-19. https://www.pwc.com/mt/en/publications/taxlegal/covid-19-financial-aid-package.html. Accessed 15 Apr 2020

PwC Malta (2020b) Third financial aid package and measures introduced in light of COVID-19. https://www.pwc.com/mt/en/publications/ tax-legal/covid-19-third-financial-aid-package.html. Accessed 15 Apr 2020

Superintendent of Public Health (2020a) Mitigation Conditions and Guidances. In: Heal. Promot. - COVID-19. https:// deputyprimeminister.gov.mt/en/health-promotion/covid-19/Pages/ mitigation-conditions-and-guidances.aspx. Accessed 10 Jun 2020

Superintendent of Public Health (2020b) Protection of Vulnerable Persons Order, Public Health Act. http://www.justiceservices.gov. $\mathrm{mt} /$ DownloadDocument. $\operatorname{aspx}$ ?app=lp\&itemid=30044\&1=1. Accessed 15 Apr 2020

Times of Malta (2020a) No new coronavirus cases overnight. In: Times of Malta. https://timesofmalta.com/articles/view/no-newcoronavirus-case-overnight-minister.794411?utm_source $=$ tom\&utm_campaign=newsletter\&utm_medium $=$ email\&utm content $=2020-05-26$. Accessed 10 Jun 2020

Times of Malta (2020b) Masks to be required when shopping or on the bus. In: Times of Malta. https://timesofmalta.com/articles/view/ masks-to-be-required-when-shopping-or-on-the-bus. 789347. Accessed 10 Jun 2020

Times of Malta (2020c) Price of disposable masks, face shields, capped. In: Times of Malta. https://timesofmalta.com/articles/view/price-ofdisposable-masks-face-shields-capped.789815. Accessed 10 Jun 2020

Times of Malta (2020d) Israel removed from list of "safe corridor" destinations. In: Times of Malta. https://timesofmalta.com/articles/ 
view/israel-removed-from-list-of-safe-corridor-destinations. 798639. Accessed 15 Jun 2020

Times of Malta (2020e) No coronavirus tests for tourists arriving from 19 "safe corridor" territories. In: Times of Malta. https:/timesofmalta. com/articles/view/no-coronavirus-tests-for-tourists-arriving-from19-safe-corridor.795846. Accessed 11 Jun 2020

Times of Malta (2020f) Public health emergency lifted, travel allowed. In: Times of Malta. https://timesofmalta.com/articles/view/legal-noticeenabling-travel-to-and-from-22-countries-published.798852?utm source $=$ tom \&utm_campaign $=$ newsletter $\& u$ tm_medium $=$ email\&utm_content=2020-06-16. Accessed 16 Jun 2020

Times of Malta (2020g) No guarantee that second COVID-19 wave will not take place - pathologists. In: Times of Malta. https:// timesofmalta.com/articles/view/no-guarantee-that-second-covid19-wave-will-not-take-place.795873?utm_source=tom\&utm campaign $=$ newsletter\&utm $\_$medium $=$email $\&$ utm_content $=2020$ 06-02. Accessed 11 Jun 2020

Times of Malta (2020h) Number of unemployed more than doubles in pandemic. In: Times of Malta. https://timesofmalta.com/articles/ view/massive-increase-in-number-of-people-registering-foremployment.793697. Accessed 11 Jun 2020

Times of Malta (2020i) Professionals call for health and economic considerations to be "balanced." In: Times of Malta. https:// timesofmalta.com/articles/view/professionals-call-for-health-andeconomic-considerations-to-be.793988. Accessed 11 Jun 2020

Times of Malta (2020j) Cash vouchers, cheaper fuel and lower tax on property sales to boost economy. In: Times of Malta. https:// timesofmalta.com/articles/view/cash-vouchers-cheaper-fuel-andlower-tax-on-property-sales-to-boost.797253. Accessed 11 Jun 2020

TVM (2020a) Government: No punishments for not wearing face masks TVM News. In: TVM. https://www.tvm.com.mt/en/news/nopunishments-for-not-wearing-face-masks/. Accessed 10 Jun 2020

TVM (2020b) See the businesses and shops that will open from Friday TVM News. In: TVM. https://www.tvm.com.mt/en/news/see-thebusinesses-and-shops-that-will-open-from-friday/. Accessed 10 Jun 2020
TVM (2020c) Health services which were suspended are to resume on Friday - TVM News. In: TVM. https://www.tvm.com.mt/en/news/ health-services-which-were-suspended-are-to-resume-on-friday/. Accessed 10 Jun 2020

TVM (2020d) From Friday: Mass during funerals, preferably in an open environment - TVM News. In: TVM. https://www.tvm.com.mt/en/ news/from-friday-mass-during-funerals-preferably-in-an-openenvironment/. Accessed 10 Jun 2020

TVM (2020e) Remain vigilant: Instead of spreading in the community, Covid-19 can spread sporadically - TVM News. In: TVM. https:// www.tvm.com.mt/en/news/remain-vigilant-instead-of-spreadingin-the-community-covid-19-can-spread-sporadically/. Accessed 11 Jun 2020

TVM (2020f) Covid-19: Beds replace chairs in University halls - TVM News. In: TVM. https://www.tvm.com.mt/en/news/covid-19-bedsreplace-chairs-in-university-halls/. Accessed 11 Jun 2020

World Health Organization (2020a) Strengthening and adjusting public health measures throughout the COVID-19 transition phases. Policy considerations for the WHO European Region, 24 April 2020. World Health Organization

World Health Organization (2020b) COVID-19 Strategy Update. Geneva

World Health Organization (WHO) (2020) WHO Director-General's opening remarks at the media briefing on COVID-19 - 11 March 2020. https://www.who.int/dg/speeches/detail/who-directorgeneral-s-opening-remarks-at-the-media-briefing-on-covid-19\% 2D\%2D-11-march-2020. Accessed 15 Apr 2020

Worldometer (2020) Coronavirus Cases. Worldometer 1-22

Xuereb M (2020) Doctors denounce 'unnecessary gamble' with lives. In: Times of Malta. https://timesofmalta.com/articles/view/doctorsdenounce-unnecessary-gamble-with-lives.795688?utm_source= tom\&utm_campaign=newsletter\&utm_medium =email $\& u$ tm content $=2020-06-01$. Accessed 11 Jun 2020

Publisher's note Springer Nature remains neutral with regard to jurisdictional claims in published maps and institutional affiliations. 